\title{
Translation Effects of the Appreciation of Ugliness in Red Sorghum
}

\author{
Leyang Wang \\ English Department \\ North China Electric Power University (Baoding) \\ Baoding, China
}

\begin{abstract}
Mo Yan's appreciation of ugliness is embodied in many aspects. This essay takes the detailed description of terrifying things in Red Sorghum as an example to analyze the translation effects from the perspective of Chesterman's professional norms. Research indicates that Goldblatt abide by the three sub-norms and create almost the same terrifying effects with the original text. However, he ignores certain deepburied terrifying effects created by certain Chinese expressions. Thus, it is essential for translators to analyze the original text thoroughly before translation and try their best to create the same aesthetic effects in their translation.
\end{abstract}

Keywords-professional norms; Red Sorghum; appreciation of ugliness; translation strategy

\section{INTRODUCTION}

Mo Yan, one of the famous Chinese contemporary writers, won the Nobel Prize in Literature in October 2012. Goran Malmqvist, the only judge in the committee who understands Chinese, suggests that capable and responsible translators are in urgent need to help Chinese literary works comprehended and appreciated in the world by those who do not speak Chinese. Some of Mo Yan's works have been translated into English, which should be contributed to the American Sinologist Howard Goldblatt. Mo Yan's representative work Red Sorghum: A Novel of China is translated by him.

Since Mo Yan's winning the Nobel Prize in Literature, the research on the translation of Red Sorghum: A Novel of China has become a hot point. Some scholars analyze its translation from different theoretical points of view, such as memetics, modern hermeneutics, reception theory, rewriting theory, skopos theory, etc. Most of those researches aim at discussing how cultural elements influence the translation strategies and what the effects are. Some analyze the translation methods of certain types of linguistic units, such as culture-loaded words, dialects, color words, marked collocations, etc. The translation effects of the unique writing style of the original author or the original novel have been temporarily less discussed yet.

Mo Yan's representative work Red Sorghum: A Novel of China is a famous contemporary Chinese novel, which represents Mo Yan's unique writing style to its full. Take the appreciation of ugliness as an example. The appreciation of ugliness means that writers describe ugly things in detail or

Supported by "the Fundamental Research Funds for the Central Universities", 2014QN45 amplify the ugly side of beautiful things on purpose, which renders readers feel uneasy, even lousy, and terrified to some extent when reading those texts. This unique writing style breaks the normal aesthetic viewpoints in literature and brings originality and strangeness to the readers. To a certain degree, it can also be considered as a new kind of aesthetic enjoyment. And it is commonly agreed that this kind of exploration within the field of aesthetic viewpoints may enhance and enrich the expressive force of language.

Translation is a kind of communication between two different languages. Can Howard Goldblatt's translation represent the uniqueness of Mo Yan's writing style? Hereby, this essay explores the translation effects of the appreciation of ugliness in Red Sorghum: A Novel of China.

The appreciation of ugliness is embodied in many aspects, such as the detailed description of terrifying things, describing the ugly side of the beautiful things, using coarse language, etc. Limited by the length of this essay, the detailed description of terrifying things in the first chapter of Red Sorghum: A Novel of China is discussed in this essay.

\section{THEORETICAL FOUNDATION}

Competent professional translators are often deemed as norm authorities, whose translation behaviors are accepted as norm-setting. They do translations under the guidance of certain translation norms consciously or subconsciously. Conversely, the theories of translation norms can help researchers explore translators' translation effects, translation process and translation strategies. Accordingly, this essay discusses the translation effects of the appreciation of ugliness from the view of Chesterman's professional norms.

Andrew Chesterman categorizes translation norms into expectancy norms and professional norms. The latter, regarded as translation process norms, is formulated by three sub-norms: the accountability norm, the communication norm, and the relation norm.

The accountability norm means that a translator should act in such a way that the demands of loyalty are appropriately met with regard to the original writer, the commissioner of the translation, the translator himself or herself, the prospective readership and any other relevant parties. It is an ethical norm, concerning professional standards of integrity and thoroughness. The communication 
norm means that a translator should act in such a way as to optimize communication, as required by the situation, between all the parties involved. It is a social norm, which specifies the translator's role as a communicator in his own right. The relation norm means that a translator should act in such a way that an appropriate relation of relevant similarity is established and maintained between the source text and the target text. It is a linguistic norm, demanding the establishment and maintenance of an appropriate relation between the source and the target texts, aiming at achieving the effect of relevant similarity.

It is commonly agreed that Goldblatt's translation is a kind of creative betrayal. He does not try to achieve linguistic equivalence in his translation. Instead, he aims at achieving the same effects by means of rewriting, addition, deleting or adjusting certain items. Can he achieve the same effects with the original text in doing so? This essay explores the answer at issue by employing Chesterman's professional norms to the comparison and analysis of the original and translated texts in Red Sorghum: A Novel of China.

\section{DATA COLLECTION}

Goldblatt says that his translation is based upon the Taipei Hong-fan Book Co. 1988 Chinese edition, which restores many cuts made in the mainland Chinese edition, published in 1987 by the Liberation Army Publishing House in Beijing. Thus, the original texts analyzed in this essay are selected from the Hong-fan edition in order to ensure the correctness of the analysis. There is only one English edition translated by Howard Goldblat. Until now, no other translators have translated this novel into English. Therefore, the translated texts are selected from Goldblatt's translation, published by Penguin Books.

The appreciation of ugliness is embodied in many aspects, such as the detailed description of terrifying things, describing the ugly side of the beautiful things, using coarse language, etc. Limited by the length of this essay, only the detailed description of terrifying things in chapter one, entitled Red Sorghum, will be selected and analyzed, which involves the description of the terrifying death scenes of six different kinds of people: the three hundred fellow villagers, Uncle Arhat, highwayman, Wang Wenyi's wife, Big Tooth $\mathrm{Yu}$, my Grandma, and that of two black mules.

\section{COMPARISON AND ANALYSIS}

Mo Yan's aesthetic viewpoint contrasts sharply with most of his counterparts in China who tend to present the positive and beautiful sides of life in their works, while Mo Yan likes to present the truth of life through the description of the negative and ugly sides. Red Sorghum: A Novel of China perfectly embodies his unique aesthetic viewpoint. At the beginning of this novel, the author expresses his general aesthetic principle:

Northeast Gaomi Township is easily the most beautiful and most repulsive, most unusual and most common, most sacred and most corrupt, most heroic and most bastardly, hardest-drinking and hardest-loving place in the world.
There are four pairs of antonyms in this sentence: beautiful and repulsive, unusual and common, sacred and corrupt, heroic and bastardly, which express Mo Yan's attitude towards his hometown. In most writers' eyes, the word "hometown" suggests warmness, sweetness and beauty, while in Mo Yan's eyes, his hometown is ugly. It does not mean that the author dislikes or even hates his hometown. On the contrary, he just wants to bring the real side of his hometown to the readers. It can be said that he breaks the general literary rule that requires writers to avoid describing the negative sides of life in their works. Instead, he attaches great importance to the description of ugliness and presents ugliness in his works, aiming to expose the truth of life to the readers.

In Red Sorghum: A Novel of China, Mo Yan expresses his viewpoint on the appreciation of ugliness through the description of general visual effects, point of view, colors, sound and movement. Accordingly, the comparison and analysis focus on the above mentioned aspects.

\section{A. General visual effects}

\section{Example 1}

Chinese version:

Sān bāi dūo gè xiāng qīn dié gŭ zhěn bì, chēn shì láng jí, liú chū de xiān xuè guàn gài le yī dà piàn gāo liáng, bă gāo liáng xià de hēi tŭ jìn pào chéng xī ní, shì tā mén bá jiǎo chí huăn.

English version:

Three hundred fellow villagers, heads pillowed on their arms, were strewn across the ground, their fresh blood turning the black earth into a sticky muck that made walking slow and difficult.

This sentence describes the terrifying scene of the three hundred dead fellow villagers, who are neighbors of my father. Seeing their corpses greatly terrifies him, a little boy at that time. The detailed description of those corpses helps readers appreciate the terrifying scene.

The translation is comparatively perfect, yet three words: dié gŭ láng jí and gāo liáng are not translated into English. Dié gŭ means "one's legs piled upon other ones' ", describing the posture of the dead body. It does not mean that every corpse remains in this posture. The author employs specific item, i.e. legs, with the aim to describe the general visual effects of the three hundred dead fellow villagers strewn across the ground. The translator only translates the word zhěn bì, i.e. heads pillowed on their arms, without completely representing the miserable situation. Láng jí means "to be scattered about in a mess", just like the messy nest of a wolf. It indicates that the three hundred corpses are scattered across the ground in a mess. If the translator fails to translate this word, the messy visual effect thus cannot be completely exhibited to the readers. Gāo liáng, meaning "sorghum" in English, is a type of grain commonly seen in Gaomi Northeast Town, which signifies the theme of this novel. Because of its being easy to be planted, it signifies the staunch life force of human beings at that hard time. In the original text, the word gāo liáng appears twice, 
emphasizing that the extensive sorghum field forms the background of the corpses. In this way, corpses are foregrounded. The scene is more terrifying, and the terrifying situation and the life force of human beings are connected closely. When gāo liáng is not translated, the connection of the terrifying scene with the theme of the novel is missing. Accordingly, the terrifying scene cannot stand out of the background.

\section{B. Point of View}

\section{Example 2}

\section{Chinese version:}

Fù qīn bìng méi yǒu lì kè rèn chū luó hàn dà yé. Fù qīn kàn dào le yī gè bèi dă làn le de rén xíng guài wù. Tã bèi jià zhe, ȳ kē tóu hù ér wāi xiàng zuŏ, hū ér wāi xiàng yòu, tóu dǐng shàng de xuè gá jiā xiàng luò shuĭ de hé tān shàng chén diàn xià nà céng guāng huá de ní, yòu zāo yáng guāng bào shài, zhòu le biānr, liè le wénr.Tā de shuāng jiăo huá zhe dì miàn, zài dì shàng huá chū yī xiē qū qū zhé zhé de huā wén.

\section{English version:}

Father didn't recognize him right away; he seemed just a strange, bloody creature in human form. As he was dragged up to the rack, his head turned to the left, then to the right, the crusty scab on his scalp looking like the shiny mud on the riverbank, baked by the sun until it wrinkles and begins to crack. His useless feet traced patterns in the dirt.

These sentences describe the terrifying situation that Uncle Arhat was tortured almost to death by the puppet soldiers. The author details the blood on his head, and the movement of his head and feet. The terrifying detailed description makes readers feel like vomiting. Besides the detailed description, the terrifying effect can be contributed to the point of view. In the original text, the words " $f u$ q qin kàn dào" indicates that this scene is presented from my father's point of view, just a little boy at that time, which enhances the realness of the terrifying scene. Because few people would doubt what is said by an innocent child.

But in the English translation, the words expressing my father's point of view is deleted. Although the rest words achieve the same terrifying degree with the original text, the realness of the terrifying scene may fade away.

\section{Colors}

\section{Example 3}

\section{Chinese version:}

Năi năi de xuè bă fù qīn de shŏu răn hóng le, yòu răn lù le;năi năi jié bái de xiōng pú bèi zì jǔ de xuè răn lü le, yòu răn hóng le. Qiāng dàn shè chuān le năi năi gāo guì de rǔ fáng. Bào lù chū le dàn hóng sè de fêng wō zhuàng zǔ zhī. Fù qīn kàn zhe năi năi de rǔ fáng. Wàn fēn tòng kǔ. Fù qīn wŭ bù zhù năi năi shāng kōu de liú xuè, yăn jiàn zhe suí zhe xiān xuè de liú shī, năi năi liăn yù lái yù cāng bái, năi năi de shēn tǐ yuè lái yuè qīng piāo, hăo xiàng suí shí doū hui fềi zoŭ.

English version:
Her blood stains his hand red, then green; her unsullied breast is stained green by her own blood, then red. Bullets have pierced her noble breast, exposing the pink honeycomb beneath it, and Father is in agony as he looks down at it. He cannot staunch the flow of blood, and as he watches it flow he can see her face pale. Her body grows so light it might float up into the air.

The blood of human is red, contrasting sharply with green. So it is quite impossible that my father's hand is stained green by my grandma's blood. The reason why the author writes in this way is to make sharp contrast by using color words and intensify the terrifying scene, which is not real but imaginative. One possible explanation may be that my father is extremely terrified and scared by the blood gushing out of my grandma's body. He wants to save his mother, but he is at a loss and flusters. The green color is not the real color he has seen, but the illusioned color he has seen when he has no idea what to do. The two color words enhance the terrifying degree. Goldblatt rewrites various items in the original novel. One of the reasons is that he thinks it unreasonable and that target readers may feel difficult to understand the unreasonable description. However, he does not rewrite the unreasonable changes of colors here. Perhaps he has felt and accepted the terrifying effects created by the sharply contrasting colors of red and green.

The Chinese color word jié bái literally means "to be spotlessly white". It carries the connotative meaning "having unquestioned moral rectitude". The word unsullied in the English translation means "not being spoiled or made less pure". The translator translates this word into unsullied, instead of white, because he intends to indicate that my grandma is morally pure and noble. That may be the connotative meaning the original author wants to express. The English translation of the Chinese color word jié bái not only keeps the original literal meaning, but also transmits the connotative meaning. The morally pure grandma is killed by Japanese invaders. The three contrasting colors: unsullied, red and green make the terrifying scene of my grandma's death more vivid.

D. Sound

\section{Example 4}

Chinese version:

Fù qīn kàn dào sūn wŭ de dāo zi zài dà yé de ěr duŏ shàng xiàng jù mù tóu ȳ̄ yàng jù zhe. Luó hàn dà yé kuáng

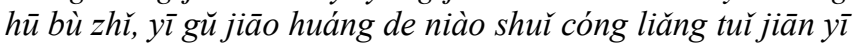
cuàn yī cuàn de cǔ chū lái. Fù qīn de tul̆ sè sè fā dŏu. Zŏu guò yì gè duān zhe bái cí pán de rì běn bīng, zhàn zài sūn wŭ shēn páng, sūn wŭ bă luó hàn dà yé nà zhī féi shuò dūn hòu de ěr duó fàng zài bái cí pán lì. Sūn wŭ gē diào luó hàn dà yé lìng yī zhī ér duǒ fàng jìn cí pán. Fù qīn kàn dào luó hàn dà yé nà liǎng zhĩ ěr duǒ zài cí pán lì tiào dòng, dă de cí pán dīng dōng dīng dōng xiăng.

English version:

Father saw Sun Five's knife cut the skin above the ear with a sawing motion. Uncle Arhat screeched in agony as 
sprays of yellow piss shot out from between his legs. Father's knees were knocking. A Japanese soldier walked up to Sun Five with a white ceramic platter, into which Sun put Uncle Arhat's large, fleshy ear. He cut off the other ear and laid it on the platter alongside the first one. Father watched the ears twitch, making thumping sounds.

Uncle Arhat is skinned alive by his fellow villager Sun Five. It is commonly said that the scene represented by these sentences is the most terrifying in this novel, the success of which should be attributed to the four words in the original version indicating sound: $h \bar{u}, c \grave{l}$, sè sè and dīng dōng dìng dong. They represent the terrifying feelings of my father from the acoustic perspective.

These words make the scene sound extremely real. Readers may feel that they are really at the spot and hear the sound. In the English version, $h \bar{u}$ is appropriately translated into screech, while the other three words are not perfectly translated.

The Chinese word $c \check{l}$ imitates the sound when liquid gushes out of a narrow passageway. Here it is employed to imitate the sound of piss. In Chinese culture, when someone is extremely terrified, he cannot control himself and may piss in that situation. Accordingly, the sound expressed by the word $c \grave{l}$ can increase readers' terrifying feelings. The phrase shot out in the English version describes the manner of liquid's gushing out of a narrow passageway, yet readers will not associate the meaning of the phrase with any sound. Thus, the terrifying feelings may decrease. In Chinese, sè sè is foundamentally used to refer to very light sound. Sometimes, it also means "shiver". Here it means that my father is so scattered that his legs quiver and the two quivering legs make very light sounds. The translator translates sè s̀̀ into knock, which means "to make a noise by striking something". This kind of knocking noise is usually louder than that signified by sè sè. Dìng dōng dīng dōng is an onomatopoeic word in Chinese, often employed to imitate euphonic and not very loud sounds. Here it is used to describe the imaginative sound the cut-off ears make in the white ceramic platter. The superficially euphonic sound in fact can create the terrifying atmosphere. In the English translation, ding dōng ding dōng is translated into thumping sound, which means "very loud and rough sound", quite contrary to ding dōng ding dōng. Thumping sound may sound not real, for fleshy ears cannot make such rough sound. The terrifying feelings fade away because of the not so real thumping sound.

When a writer employs sensory details and concrete words to create proper settings for portraying characters, readers may get the same feelings as if they were at the spot. In this passage, Mo Yan creates the terrifying settings by using different types of sounds, loud sounds contrasting with light ones, grating ones contrasting with euphonic ones. Those sounds perform like a symphony. Although the English translation creates almost exactly the same terrifying effects, it fails to imitate the symphonic effects created by various acoustic words.

\section{E. Movement}

Chinese version:
Tā de liăn shàng zhǐ shèng xià yī zhāng wán hăo wú quē de zuǐ, năo gài fēi le, năo jiāng hú măn shuāng ěr, ȳ̄ zhī yăn qiú bèi zhèn dào kuàng wài, xiàng lì dà pú táo, guà zài ěr duŏ páng. Tā de shēn tǐ luò xià shí, bă sōng ruăn de yū ní zá de sì jiàn.

\section{English version:}

All that was left of his face was the perfectly formed mouth. The fluids of his brain had oozed into his ears from the shattered scalp, and one of his eyeballs hung from the socket like a huge grape on his cheek.

With a series of vivid verbs: fêi, hú, zhèn, guà, luò, zá and jiàn, this excerpt describes the terrifying scene when Big Tooth $\mathrm{Yu}$ is shot to death. These words represent the dynamic character of the terrifying scene. The two verbs $h u$ and guà are appropriately translated into ooze and hang, while the rest five verbs are either missing or not properly translated in the English version, leading to the loss of the dynamic character of the terrifying effects.

The Chinese verb fê $i$ means "to move through the air in a distance", indicating that Big Tooth Yu's crania is shot into pieces and the pieces move through the air in a distance. The flying of the shattered crania pieces enhances the visual effects of the terrifying, just like the slow motions in the movie. However, the word "shattered" in the English version can only describes the static feature of the broken crania. In Chinese, the word zhèn means "to cause to move to and fro with jerky movements". Here it indicates that the eye balls jerk out of the eye sockets after Big Booth Yu's head being shot by the gun. He can no longer see anything because his eyes have been destroyed. The visual effects created by the verbs are very attractive. It is with his own eyes that my father has witnessed the terrifying scene. But Big Tooth Yu's eyes are destroyed in such a short time. Readers can feel the vivid sharp contrast between my father's intact eyes and Big Tooth Yu's destroyed eyes. The terrifying feelings increase naturally. But in the English version, the translator only translates the verb guà into hung, failing to translate the verb zhèn. The target readers can only feel the final state when the eyes are destroyed, without feeling the process how the eyes are destroyed. The dynamic feature of the terrifying effects loses. The Chinese verbs luò, zá and jiàn describe in details the scene when Big Tooth Yu's dead body falls onto the ground. But the translator cuts off this sentence, resulting in the loss of the terrifying effects.

\section{DISCUSSION AND CONCLUSION}

Chesterman's professional norms, formulated by three sub-norms: the accountability norm, the communication norm, and the relation norm, are regarded as process norms. We can use these sub-norms to analyze whether the translator can achieve the same effects with the original text during his translation process.

The original author Mo Yan's unique appreciation of ugliness, especially the detailed description of terrifying things, is fully represented in the first chapter of Red Sorghum: A Novel of China. Judging by the accountability norm, Goldblatt is loyal to the original writer. He appropriately keeps the author's unique style in his 
translation to the largest degree. He is also loyal to the commissioner of the translation and himself because of his high quality translation. At last, he is loyal to the prospective readers. They can not only understand the story, but also appreciate the original author's unique appreciation of ugliness.

On the aspect of communication norm, we can say that in most cases, Goldblatt optimize the communication required by the situation between all the parties involved. Take the color word unsullied as an example. He senses the connotative meaning of the Chinese word jié bái and translates it into unsullied. Thus, my grandma's nobility remains. Although the red blood cannot stain my father's hand green, he translates the unreasonable changes of color properly, representing the illusioned mind of my father, who is extremely terrified by my grandma's blood at that time. However, in some sense, he does not completely transmit the deep-buried terrifying effects created subtly by certain words or phrases. We can say that occasionally, he may not optimize the communication, because the author's unique style is too subtle to appreciate.

He neglects the sharp contrast created by certain words. Gāo liáng, with the meaning "sorghum", performs the background of the terrifying scene of the three hundred dead fellow villagers. The translator cuts it off in his translation, decreasing the sharp contrast created by the background formed by the word sorghum and the foreground formed by the terrifying three hundred dead bodies. He does not optimize the general sight effects of the terrifying scene. In addition, he neglects the contrast by various types of sounds created by Chinese onomatopoeic words. The loud sound created by the word screech remains, but readers cannot feel the light sounds created by three Chinese words: $c \grave{c}$, s̀̀ sè and dīng dōng dīng dōng. He may not acoustically optimize and communicate the terrifying effects.

Mo Yan tells the story from different points of view: my father's view, the author's view, my grandma's view, etc., which is his unique writing style, too. Sometimes, Goldblatt pays less attention to the effects created by the point of view and cuts off the expressions indicating it. My father is still a child at that time. The terrifying scene described from my father's point of view makes it more real and credible. If that expression indicating the point of view is cut off, the real and credible effects of the terrifying scene will decrease. It can be said that, in this sense, Goldblatt does not optimize the communication between the original text and the target readers.

On the aspect of relation norm, research indicates that in most cases, Goldblatt has established and maintained the appropriate relation of relevant similarity between the source text and the target text. With his proper selection of words and expressions, he creates almost the same terrifying effects with the original text. However, he sometimes ignores the subtle and implied connotative meanings and effects of certain words, for example, the series of verbs. Verbs are more frequently used in Chinese language than English. The continuous usage of verbs may add the dynamic features. But the translator tends to use more nouns, which is a feature of
English language, resulting in the loss of the dynamic realness of the terrifying effects.

All in all, research in this essay shows that in order to achieve the same effects, especially those effects deeply implied in the original text, translators are required to analyze the style of the original text thoroughly and try their best to achieve the same effects in their translations.

\section{REFERENCES}

[1] A. Chesterman. Memes of Translation. Shanghai: Shanghai Foreign Language Education Press, 2012.

[2] Mo Yan, Honggaoliang Jiazu. Taipei: Hong-fan Book Co. 1988.

[3] Mo Yan, Red Sorghum: A Novel of China. Warwickshire: Penguin, 1993. 